\title{
ORIENTAL CONCEPTS OF CIVIC ACTIVISM
}

\author{
Nurali Shodiev, \\ A doctoral candidate at the Academy of Public Administration under the \\ President of the Republic of Uzbekistan \\ Crossref

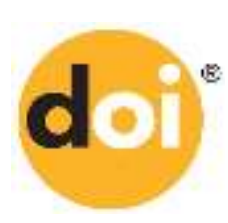 \\ http://dx.doi.org/10.26739/2433-202x \\ Issue DOI http://dx.doi.org/10.26739/2433-202x-2017-9-9 \\ Article DOI http://dx.doi.org/10.26739/2433-202x-2017-9-9-8
}

\begin{abstract}
This article illustrates initial foundation of civic activism and its concepts created in the East. It scrutinizes the oriental concept of civic activism as a factor of an active citizen and social conditions to encourage citizens to be actively involved in processes in accordance with the views of Central Asian scholars.
\end{abstract}

Key words: civic activity, state and society, civic consciousness, common interests, participation in public work.

In the past, the interaction between state and citizens alongside with citizens' striving to manage a society, and groups' attempts to establish new statehood created opportunities to demonstrate personal civic activity. To look back at some ancient states, citizens used to be given limited opportunities to carry out their civil activities by only engaging them in common events. In the ancient societies, a state would be considered as heavenly given fortune and order. State structuring used to be admitted as a gift from the Heavens according to the ancient world. These views were the Social science and humanities

Nurali Shodiev 
essential to obey a government and adhere its rules.

In the 9-8 centuries BC the ancient philosophical trend experienced evolutional transition from religion oriented heavenly views to more concrete visions. This process is linked with Zoroastrianism and the Zoroaster's views.

According to the sacred book of Zend-Avesta, Zoroastrians considered a state to be an illustration of heavenly power on the Earth as well as endless struggle between good and evil. It was stressed out that each man existed to live his life with the purpose of bringing more light and struggling against darkness. That was the reason why powerful people and monarchs of that time bared the commitment of doing good things by expanding their territories and countering the power of evil. ${ }^{1}$ It also reflected citizens' mindset and their activities which served to be committed to doing more good things and struggling against evil ones. As a result, this idea encouraged the citizens to have common targets and attempts in their lives to unite in their participation in state's activities and government.

The scholars allege that the formation of civic activism has a relationship with Zoroastrianism converted in the territory of Khorezm. ${ }^{2}$

The people who lived three thousand years ago obtained the concept of common heritage of mankind due to the Zend-Avesta which served to change their mindset and culture. Here, the book of Zend-Avesta sets forward the idea of Monotheism by eliminating the idea of Polytheism within various tribes and small groups of people. According to this belief, irrespective of a man's belonging to a group, tribe or race, and his home residence, he is the slave of only God and He only can protect His obedient. ${ }^{3}$ By emphasizing Monotheism, the Zend-Avesta unites different tribes and minorities upon single trust and ideology, also propagandas to come together around common to all interests. The sacred book summons people to the idea of good protecting the light and staying away from evil deeds and darkness. ${ }^{4}$

The Zend-Avesta used to be spread in the Uzbek territory as a source to combine the nature, society and human by spiritual and behavioral criteria assuring people to learn the world surrounding us, its development and the meaning of this life.

The Zend-Avesta is based on the three behavioral rules such as "Good

\footnotetext{
1 “The Zend-Avesta" (translated by A.Mahkam) . - P. "Sharq" publishing house. 2001.

2 D.V.Artyukhovich. Person's civil activity: socio-philosophical analysis: dis. PhD 09.00.11.-Stavropol, 2002. P.46.

${ }^{3}$ D.V.Artyukhovich. Person's civil activity: socio-philosophical analysis: dis. PhD 09.00.11.-Stavropol, 2002. p.46.

4 "The Zend-Avesta" (translated by A.Mahkam) . - P. "Sharq" publishing house. 2001. - pp. 6-8.
}

Social science and humanities

Nurali Shodiev 
thoughts, good words, and good deeds". By following those three rules people were able to demonstrate their civil activities on a high level.

In addition, this system of religion pays a great attention to the idea of working hard, protecting and appreciating the society and the land that he lives in. It was also important to seal the idea of Good thoughts, good words, and good deeds into each man's mindset. In order to adhere this triple rule, each man was supposed to work honestly for the sake of his society, protect his motherland from rivals, and show his ambitiousness and loyalty to his motherland.

The elements of historical concept of civic activism can also be observed in the ancient India. It is related to formation of public social structures. Indian castes used to be inherited and it was prohibited to convert from one caste to another. Caste-based differences were the basis of the elements of civil activity. ${ }^{5}$ The Brahman would conduct prayers for society; it was their job to pray for the sake of other people; the Kshatriya would provide military defense and safety of a state; the Vaishya were committed to work in order to supply the Brahman and the Kshatriya with food, clothes and other needed stuff for living. This interrelated mechanism used to be used to develop their society. The sense of responsibility for being worth his caste led to developing the principles of civil activity.

In the East, the concept of "Well-being people" used to be essentials for developing a society. In the example of this concept, the priorities of civic activism were identified.

According to Farabi's view, a man, by his nature, is not able to create all facilities in order to satisfy his needs and to develop. For being satisfied in many terms, he needs other people with various professions and their assistance. This is common to all mankind. People are required to unite in one community and society in order to achieve life satisfaction. In this community, each person tries to learn a profession in accordance with his nature, talent and ability as well as to develop the art of his job. That is why people (of different nations and religions) inhabiting in various places is joined in different communities. 6

He also writes about an important role of civic activism in civil society. According to the scholar, "the city where people help each other to gain happiness and do all good deeds is considered to be The Well-being City that is The City of Well-being People. People in any city who do good deeds and

5 The ancient Indian philosophy. Inception period. М.:Мысл. 1972

${ }^{6}$ Abu Nasr Farabi. The city of well-being people. -T.: "Yangi asr avlodi" publishing house, 2016. - p. 131 
help for the sake of common interests and happiness are the Gifted Nations". Though, symbolically, if a man's all body parts are safe and sound he turns an ideal person, subsequently, a city with well-behaved and helpful inhabitants turns a city of well-being people". ${ }^{\prime}$

The difference of Farabi's dream of an ideal community with the evil existing one is that people in that society bring together in order to achieve happiness and do help each other on this way. It is evident that Farabi prioritizes the requirements for people to possess the feature of civil activeness so that to establish gifted community. He also describes the main criterion of civic activism by saying that the primary basis of uniting people is their "humanism".

One of the most important concepts of civic activism is considered "Javonmardlik" (that is altruism). It is reflected in Abu Raikhan Beruni's works. The essence of this concept stands for that a perfect man does not possess more than his life and belongings and owns only those things legally belong to him. If a man takes the responsibility of another person's hardship and shares his possessions given by God with people in need, he is called as Javonmard (an altruist). Javonmard was famous for his kindness and generousness. Today Javonmard is a man of well-behaviour, mercifulness, patience, and respect" .8

Beruni stands for the idea that the level of satisfaction of daily needs determines the level of civil activity. The observance of social justice principles is the most significant factor for providing citizens' welfare in a society. ${ }^{9}$

Yusuf Khos Khojib in his work entitled "Khutadgu bilig" human's social significance, civic behavior and its role and social tasks were analyzed in different directions. According to Yusuf Khos Khojib, civic activism is determined as having sympathy to others' trouble and avoiding selfishness to be a patriot for other people's interests. ${ }^{10}$

The great personality Alisher Navoi left rich scientific heritage in his works. He was the one who demonstrated superior examples of civil activity. He thoroughly explained civil related characteristics such as justice, generousness, mercifulness, ambitiousness, honesty, straightforwardness, patriotism, and bravery. In the view of Alisher Navoi, only people possessing the abovementioned features and intellectuals would be able to build a civil

\footnotetext{
${ }^{7}$ Abu Nasr Farabi. The city of well-being people. -T.: "Yangi asr avlodi" publishing house, 2016. - p. 239.

8 A.R.Beruni. Mineralogy: collection of data for mineral sciences. - M., 1963. - p. 14.

${ }^{9}$ A.R.Beruni. India. Works. Chapter 2. - T.: “Fan” publishing house. 1965. pp.70, 125, 161.

${ }_{10}$ Yusuf Khos Khojib. Khutadgu bilig. - Tashkent: "Akademnashr" publishing house, 2015.
}

Social science and humanities

Nurali Shodiev 
society.

Navoi illustrates civic activism in the mask of "the wise" as he describes above. "The wise" are those who combine satisfaction of self-needs with others' needs; those who enjoy serving and existing for a society and its nation; those who do anything keeping in mind the consequences of each action and situation; those who have a deep sense about that the life is short and it has its end. This kind of people are the citizens who are usually free, courageous, honest, responsible, modest, patriotic, believing in God, sympathetic, able to struggle against any violence, and having his personal opinion. ${ }^{11}$

In "Khamsa", the great five poems, written by Alisher Navoi, each work encompasses the idea of civil activity. In the example of Farkhad, Shirin, Leyli, Majnun, Iskandar, Socrates, and Aristotle described in the works entitled "Farkhad and Shirin", "Leyli and Majnun", "Saddi Iskandari" ("Wall of Iskandar") and other poems he showed the combination of the high-level behavior and humanity based civil characteristics. Navoi prioritizes such features as humanity, loyalty, and respect to others, patriotism, self-sacrifice for the sake of people, charity, and kindness.

We are aware from the history that a society has never been developed at random; it has been directed by mankind. The oriental concept of civic activism focuses on a citizen. A citizen is a person possessing those civil characteristics.

The basis of a society comes from people's social unity in terms of their common interests and tasks. Eventually, people's civic activism depends on being conscious of their independence, their rights and duties, combining their interests with those of community, and taking care about other people living in that society.

11 Alisher Navoi. Khayratul-abror. - T.: “Adabiyot va san'at" publishing house. 1974. -pp. 35-38 


\section{References}

1. "The Zend-Avesta" (translated by A.Mahkam) . - P. "Sharq" publishing house. 2001.

2. D.V.Artyukhovich. Person's civil activity: socio-philosophical analysis: dis. PhD 09.00.11.-Stavropol, 2002. P.46.

3. "The Zend-Avesta" (translated by A.Mahkam) . - P. "Sharq" publishing house. 2001. - pp. 6-8.

4. The ancient Indian philosophy. Inception period. М.:Мысл. 1972

5. Abu Nasr Farabi. The city of well-being people. -T.: "Yangi asr avlodi" publishing house, 2016. - p. 239.

6. A.R.Beruni. India. Works. Chapter 2. - T.: "Fan" publishing house. 1965. pp.70, 125, 161.

7. Yusuf Khos Khojib. Khutadgu bilig. - Tashkent: "Akademnashr" publishing house, 2015.

8. Alisher Navoi. Khayratul-abror. - T.: “Adabiyot va san'at” publishing house. 1974. -pp. 35-38. 